\title{
Does where you live affect how much you spend on transit? The link between urban form and household transit expenditures in Mexico City
}

\section{Erick Guerra}

University of Pennsylvania

erickg@upenn.edu

\section{Article history:}

Received: October 11, 2016

Received in revised form: April

28, 2017

Accepted: May 9, 2017

Available online: August 3, 2017

\section{Introduction}

Each morning, Marta leaves her house on the outskirts of Mexico City at 6:30 a.m. to arrive at her cleaning job by 9 a.m. The two-and-a-half-hour one-way commute costs around a quarter of the daily minimum wage, and involves two long walks and multiple transfers on minibuses and the metro system (WRI Ross Center for Sustainable Cities, 2011). Though extreme, this type of commute is hardly unusual in Mexico City or other large Latin American, Asian, or African cities. In cities as diverse as Mumbai, Dakar, and Bogota, many suburban residents face long and expensive trips on multiple modes of public transportation to reach centrally located jobs.

This paper explores the empirical relationships between measures of urban form and how much households spend on transit in the Mexico City metropolitan area (henceforth Mexico City). Transportation costs—including travel time—are central to early theories and models of housing location

Copyright 2017 Erick Guerra

http://dx.doi.org/10.5198/jtlu.2017.948

ISSN: 1938-7849 | Licensed under the Creative Commons Attribution - Noncommercial License 3.0

The Journal of Transport and Land Use is the official journal of the World Society for Transport and Land Use (WSTLUR) and is published and sponsored by the University of Minnesota Center for Transportation Studies. This paper is also published with additional sponsorship from WSTLUR. 
and urban form (Alonso, 1960, 1964; Brueckner, 1987; Mills, 1972; Muth, 1969), and popular explanations of real estate markets- households drive far enough out from an urban center until they can qualify for a home mortgage. Transit accessibility, furthermore, features prominently into the location decisions of households that use transit (Cervero, 2007: Glaeser, Kahn, \& Rappaport, 2008). This study focuses specifically on household transit expenditures for three primary reasons.

First, the relationship between urban form and travel costs is relatively unstudied, despite the large and growing body of literature about the empirical relationship between urban form and travel behavior (Boarnet, 2011; Brownstone, 2008; Ewing \& Cervero, 2001, 2010; Stevens, 2017). Most existing work on the link between urban form and travel is motivated by a desire to reduce greenhouse gas emissions or increase physical activity through land-use policy (for examples, see Ewing, Bartholomew, Winkelman, Walters, \& Chen, 2008, or Boarnet, 2006). As a result, the literature tends to focus on mode choice, number of non-motorized trips, or vehicle kilometers of travel. Researchers treat travel cost as a predictor of whether, how much, and by what modes people travel (for an overview, see Small \& Verhoef, 2007, or Small \& Winston, 1999), rather than an important outcome of urban form. Where scholars have examined urban form and travel costs, the emphasis has been on trip-tour or commute duration (for examples, see Caren et al., 2004, or Lee, Washington, \& Frank, 2009). None focus on transit costs specifically. However, travel costs and time almost certainly vary as a function of urban form. Indeed, the tradeoff between higher commute costs and larger homes on the periphery is the central feature of early models of urban form (Alonso, 1960, 1964; Mills, 1972; Muth, 1969).

Second, transit costs matter-particularly in cities with high concentrations of poverty, notable spatial manifestations of inequality, and substantial reliance on transit. In Mexico City, $80 \%$ of households use transit on a typical weekday and the poorest fifth of households spend almost a quarter of their income on transit (author's estimates using INEGI 2007) — twice as much as commonly used transportation affordability thresholds (Center for Neighborhood Technology, n.d.; Guerra \& Kirschen, 2016). Poor households are least able to reduce transit expenditures without reducing travel, since cars are expensive, non-discretionary trip distances are often too long for non-motorized modes, and wealthier households price them out of the most accessible neighborhoods. Few poor households opt for the faster speeds and higher costs of cars or taxis and there are few, if any, options to exchange slower transit speeds for lower transit expenditures. Despite Mexico City's notorious traffic congestion, door-to-door travel speeds are $22 \%$ faster by car than by transit (author's estimates using INEGI, 2007). The differences are even greater in the suburbs, where nearly all transit is road-based and gets delayed by congestion as much as or more than private cars.

Third, supporting transit use and reducing transit fares are important public policies that governments already spend substantial resources to accomplish. The Federal District government of the city proper has long spent the majority of its transportation budget on metro subsidies (Crôtte, Graham, \& Noland, 2011; Davis, 1994; Islas Rivera, 2000). Not only does this burden the local government, it makes it difficult to expand metro service. Yet just under a fifth of metropolitan trips involved the metro in 2007. Most households rely first and foremost on privately provided transit in minibuses (microbuises) and minivans (combis). If there are strong and predictable relationships between household transit expenditures and urban form, better coordinated transit and land-use planning could offer an opportunity to lower households' transportation expenditures and perhaps even reduce government subsidies. At the very least, more attention should be paid to whether land-use and transit policies are working at cross purposes. For example, recent housing policies have concentrated the growth of low-to-moderate cost housing in peripheral neighborhoods, where transportation expenditures are highest and expanding high-capacity transit is costly.

The remainder of this paper: (1) presents theoretical expectations and background data about the 
relationship between urban form and transit expenditures in Mexico City; (2) describes the statistical models and data used; (3) summarizes the results of two statistical analyses; (4) discusses their relevance to understanding the relationships between urban form and transit expenditures; and (5) concludes with several implications for planning and public policy.

\section{$2 \quad$ Urban form and daily transit expenditures in Mexico City}

Residents of Mexico City rely on a mixture of privately owned minibuses and minivans and publicly owned metro, buses, and trolleys for transit services. The metro system charges a single flat fare with free transfers while the buses charge for each transfer. However, only 3\% of all trips rely exclusively on the metro (INEGI, 2007). Like Marta, most travelers make multiple paid transfers across different transit lines and modes. A household's total daily transit spending is a function of the number of household members traveling on a given day, the number of trips they take by transit, the destination of these trips, the types of transit used, and the number of transfers made.

Urban form is related not just to the probability that a household member uses a specific transit mode or makes a transfer, but also to the number of household members, household income, and the amount that household spends on housing. Different measures of urban form, furthermore, likely have different relationships with trip distances, transit quality, and mode choice. In particular, some measures will tend to increase the probability of using transit and while others will tend to increase the cost associated with transit use, due largely to long trips with paid transfers. Below, I discuss the expected relationship between three regional measures of urban form (municipal job density, distance to a metro station, distance to the downtown) and three neighborhood attributes (population density, intersection density, and activity mix) to transit expenditures. These six metrics, or similar ones, are commonly used in studies of the relationship between urban form and travel behavior (for a more general overview of expected relationships, see Ewing \& Cervero, 2010). I then discuss the spatial variation in household composition and housing expenditures that are also correlated with urban form and transit expenditures.

\subsection{Regional measures of household location}

Where a household resides in the metropolis is likely a good predictor of how much that household spends on transit. Peripheral locations have worse job accessibility, fewer high quality transit services, and longer average trips. Suburban workers (defined as those living outside of the city proper) have commutes that are $40 \%$ longer than urban ones, with an average one-way transit commute of an hour and twenty minutes. One in five has a commute that lasts at least two hours (INEGI, 2007). One reason that suburban commutes are so long is that jobs, particularly higher paying formal jobs, are concentrated in the central parts of the metropolis. One third of all commutes go to the Federal District's four most central boroughs, which produce half of economic output. (Mexico City includes the 16 boroughs of the Federal District and 60 surrounding municipalities of the States of Mexico and Hidalgo). These trips from the periphery to the center tend to be particularly long and expensive. Examining the distribution of employment throughout the metropolis, Montejano, Caudillo, and Cárdenas (2016) conclude that Mexico City has just one dominant economic center with several emerging sub-centers. As a result, I expect higher municipal job density and more centralized residential locations to be associated with lower transit expenditures, since households have more opportunities to access employment nearby, though probably not with lower transit use.

The quality of transit supply also varies substantially by geography. The metro, which cost about half as much as single minibus fare and covered 200 kilometers in 2007, is particularly important to households' transit expenses. The municipalities that are farthest from the metro have average house- 
hold transit expenditures that are 3 to 6 times higher than the best served parts of the city (Figure 1). Although $80 \%$ of metropolitan population growth has been outside of the city proper since the first metro line opened, only a few high-capacity transit lines extend into the suburbs, which house $56 \%$ of the metropolitan population but only 11 out of 192 metro stations.

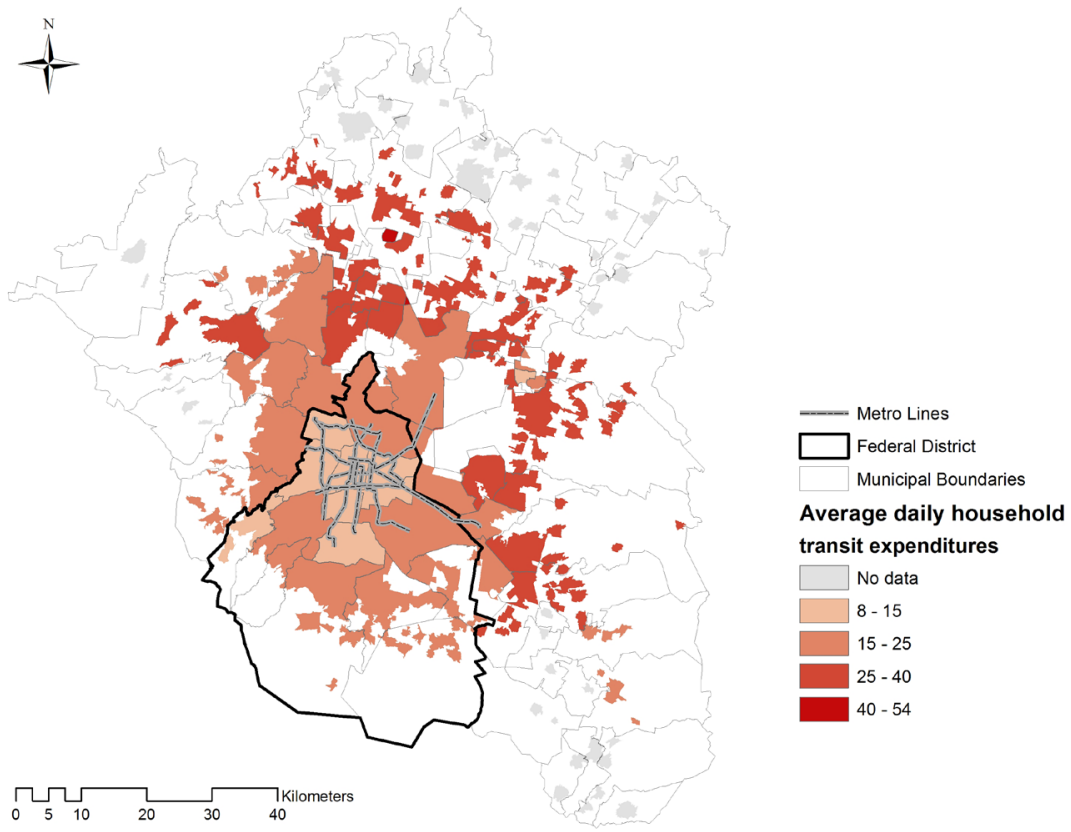

Figure 1: Household transit expenditures (in 2007 pesos) by municipality on an average weekday in 2007

Source: Compiled by author from state, municipal, and locality boundary files from the Instituto Nacional de Estadística y Geografía (INEGI, 2013) and calculations from the 2007 household travel survey (INEGI, 2007).

\subsection{Local urban form}

The relationship between transit expenses and local measures of urban form is likely to be more complicated than the relationship with regional measures of household location. Transit-friendly local built environments may increase the probability that households use transit for more trips by making transit more convenient, but decrease the amount that households spend on transit compared to a less transitfriendly neighborhood where trips are longer and more transfers are required. Denser neighborhoods with more diverse activities and more pedestrian-friendly street networks are also likely to encourage more walking and biking, which could reduce transit expenditures. Despite Mexico City's geographic size and long average commutes, $18 \%$ of commutes are by foot and $40 \%$ of all commutes last less than 30 minutes (INEGI, 2015). Long and expensive commutes to the center by poor and moderate-income suburban workers on transit may be a notable feature of Mexico City's transportation and land-use system, but Suárez, Murata, and Delgado (2016) find that the poorest workers often economize on commutes by working informal jobs close to home that are within walking distance or a short bus ride. These jobs pay less and have less job security but do not require as much time or money to be spent on transportation. Partially as a result, the distribution of commute times is remarkably similar across income groups (Figure 2). 


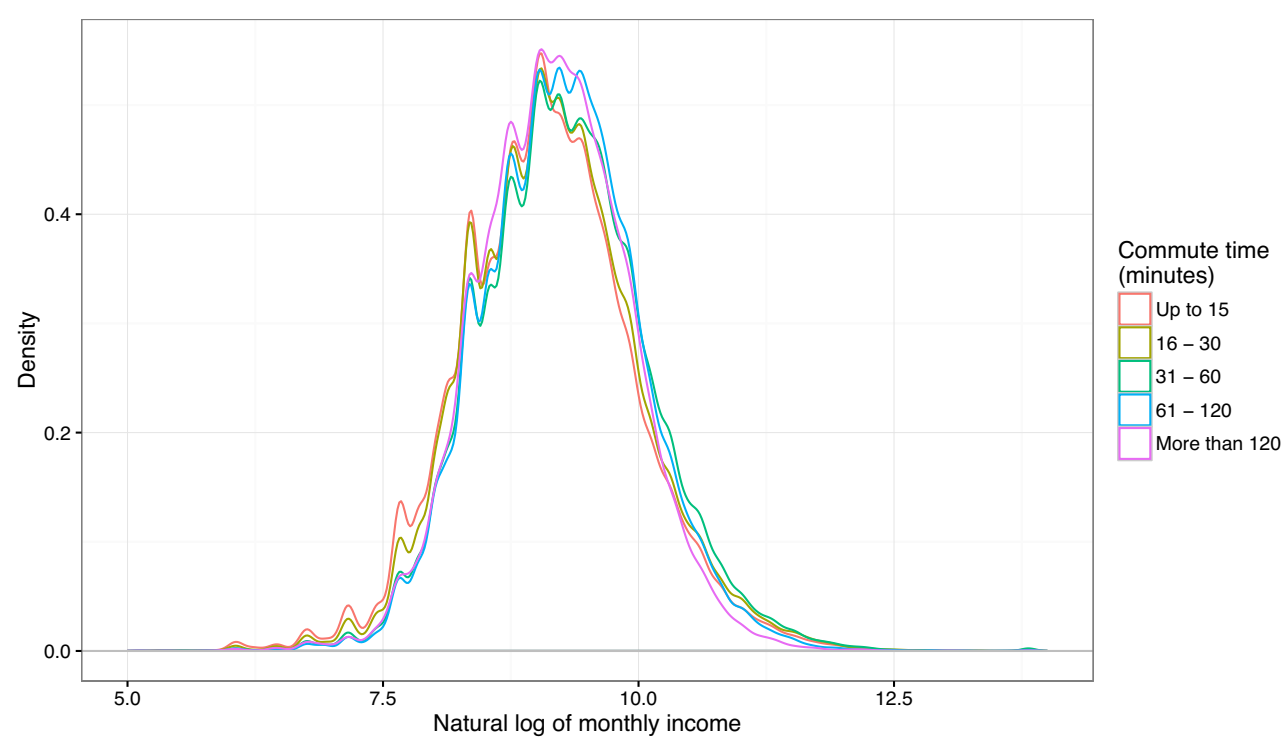

Figure 2: Distribution of household income by duration of commute to work in the Mexico City metropolitan area Source: 2015 National Population Intercensus (INEGI, 2015).

In addition to influencing trip distance and mode, neighborhood density may also affect the quality of local transit supply, since operators provide better service to neighborhoods and corridors with higher demand. Higher frequencies and more transit routes likely encourage higher rates of transit use. If better service reduces the need for transfers or increases the likelihood of a direct line to a metro station, it could also lower expenses on a given transit trip.

\subsection{Household composition, income, and rent}

Despite living in neighborhoods with lower densities, fewer types of destinations, less pedestrian-friendly streets, and worse transit accessibility, suburban residents rely on transit for a higher share of trips $(65 \%)$ than urban residents $(60 \%)$ and even use the centrally located metro for a similar share (18\% vs. 19\%) (INEGI, 2007). ${ }^{1}$ They also pay nearly twice as much on transit per day as centrally located ones (25.7 vs. 14.7 pesos). While urban form plays a role, so do socioeconomics and household composition, which also vary by geography. Suburban households earn 30\% less than central ones on average and have about 10\% more people per household. Local measures of urban form show fewer differences, with average population and street-network densities nearly identical for households above and below the median income. Wealthier neighborhoods have about $10 \%$ higher activity diversity. If urban form is not directly related to trip distance or mode choice, but is related to income, failing to account for income could lead to spurious or biased associations between urban form based on statistical models or maps of expenditures by geography.

Land prices are strongly related to both transit expenditures and the built environment both theoretically and empirically. Figure 3 plots households' transit expenditures and estimated monthly rents by 5 -kilometer increment from the central Zocalo. Although median household transit expenditures increase with distance into the most remote neighborhoods, the rent gradient flattens more quickly. Households living more than 20 kilometers from the center (37\% of all households) report similar rents to those beyond 50 kilometers. Since rental estimates do not include square footage, it is not clear through the data whether housing units are larger beyond this point. Walking through peripheral neigh-

\footnotetext{
${ }^{1}$ Note that the regional household travel survey excludes pedestrian trips. This and all other mode share figures in this paper refer to the proportion or percentage of non-pedestrian trips.
} 
borhoods or passing through them on Google Street View, even a casual observer will notice the small size of peripheral lots in Mexico City's most populous suburban neighborhoods. The average suburban household's neighborhood density (150 people per hectare) is not much lower than the average urban household's neighborhood density (180 people per hectare).
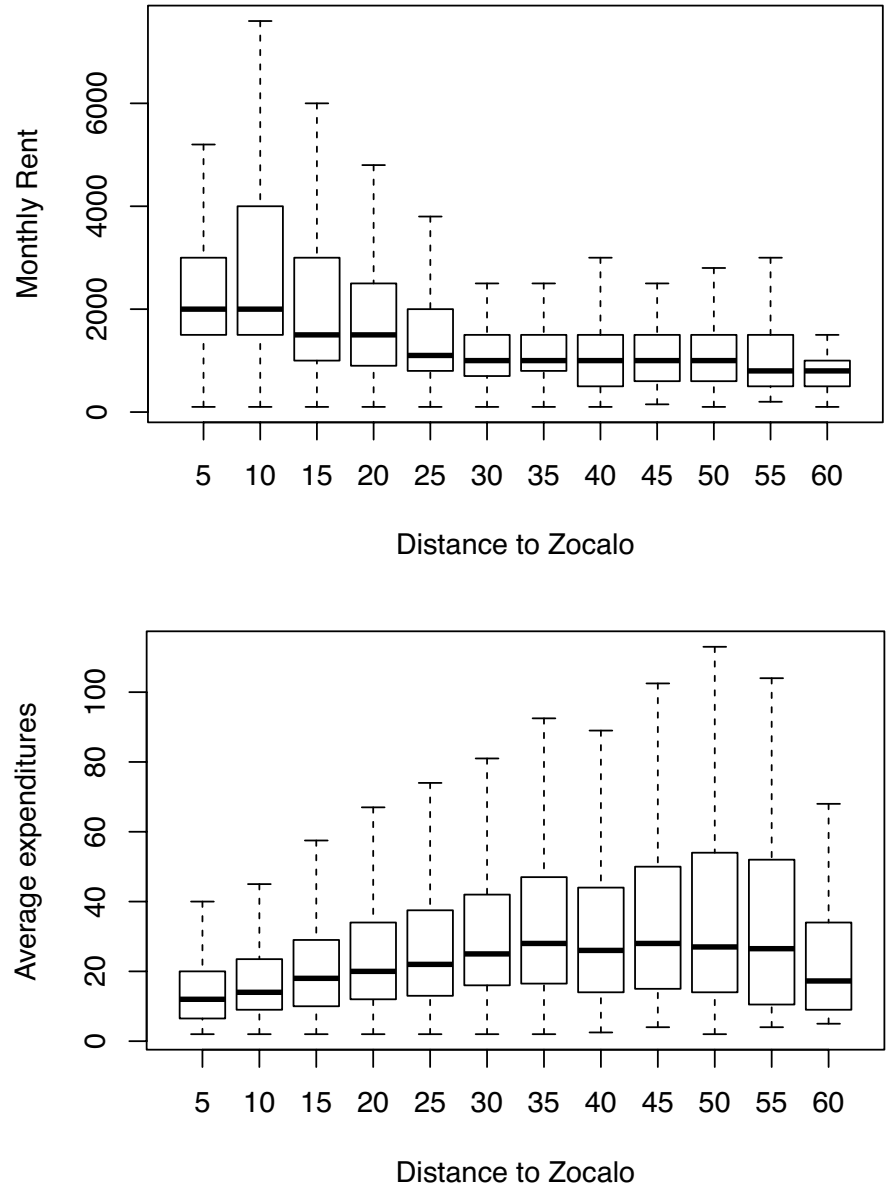

Figure 3: Boxplots of monthly rent and transit expenditures by 5-kilometer increment from the central Zocalo

Source: Compiled and calculated by author from census tract boundary files from the Instituto Nacional de Estadística y Geografía (INEGI, 2013), OpenStreetMap (2015), and the 2007 household travel survey (INEGI, 2007). Default boxplot settings are used with upper and lower arms representing 1.5 times the inter quartile range and outliers excluded.

\section{Research strategy, data, and model specification}

This analysis follows a long tradition of estimating empirical relationships between measures of the built environment and travel behavior. Instead of examining vehicle travel or mode choice, however, I predict household transit expenditures as a function of household socioeconomics and measures of the built environment where households reside, use this estimation to test research hypotheses, make inferences about the nature and importance of these relationships, and draw several broad policy conclusions.

\subsection{Data summary}

Table 1 reports the summary statistics of the 31,167 households used in the statistical analysis. These are a random sample of the 43,868 households that reported some travel on the 2007 household travel 
survey (INEGI, 2007) after removing approximately 5\% of observations due to problems matching survey data with geographic data or across datasets in the survey. ${ }^{2}$ The 2007 household travel survey contains information on approximately one percent of all households, household members, and their daily travel - including the geographic location of origins and destinations, trip purpose, trip duration, trip time, out-of-pocket expenses, and mode of travel—on an average weekday in the Mexico City metropolitan area (Zona Metropolitana del Valle de México). The survey excludes pedestrian travel and travel by children younger than six.

Table 1: Summary statistics of dependent and independent variables

\begin{tabular}{|l|c|c|c|c|}
\hline Statistic & Mean & St. Dev. & Min & Max \\
\hline Public transit use > & 0.80 & 0.40 & 0 & 1 \\
\hline Public transit expenditures & 20.13 & 20.85 & 0 & 216 \\
\hline Kilometers to the metro & 6.63 & 7.32 & 0.02 & 44.17 \\
\hline Kilometers to the Zocalo & 17.27 & 9.70 & 0.06 & 62.21 \\
\hline Jobs per hectare & 42.59 & 44.96 & 0.80 & 218.74 \\
\hline People per hectare & 168.19 & 90.94 & 0.65 & 629.12 \\
\hline Destination diversity & 0.29 & 0.17 & 0 & 0.87 \\
\hline Intersections per hectare & 2.13 & 1.42 & 0 & 25.09 \\
\hline Monthly income (000s of pesos) & 10.9 & 22.6 & 0 & 1,920 \\
\hline Income missing & 0.11 & 0.31 & 0 & 1 \\
\hline People over 6 & 4.04 & 1.93 & 1 & 24 \\
\hline People 6 or under & 0.43 & 0.74 & 0 & 7 \\
\hline Number of workers & 1.78 & 1.03 & 0 & 11 \\
\hline Average age of adults & 36 & 7 & 18 & 59 \\
\hline Has a vehicle & 0.46 & 0.50 & 0 & 1 \\
\hline Monthly rent $(000$ s of pesos) & 2.38 & 3.08 & 100 & 80 \\
\hline Rent missing & 0.14 & 0.35 & 0 & 1 \\
\hline Worker 1: central destination & 0.53 & 0.50 & 0 & 1 \\
\hline Worker 2: central destination & 0.21 & 0.41 & 0 & 1 \\
\hline Worker 3: central destination & 0.09 & 0.28 & 0 & 1 \\
\hline Worker 1: commute distance $(\mathrm{km})$ & 9.75 & 9.69 & 0 & 69.71 \\
\hline Worker 2: commute distance $(\mathrm{km})$ & 3.53 & 7.16 & 0 & 66.70 \\
\hline Worker 3: commute distance $(\mathrm{km})$ & 1.50 & 5.01 & 0 & 66.70 \\
\hline Notes: N 31,167 & & & &
\end{tabular}

Notes: $\mathrm{N}=31,167$

Like daily vehicle travel, daily household transit expenditures are a composite of several aspects of household members' behavior and form a joint discrete and continuous distribution. Just under a fifth of households reported no transit expenditures, with the remainder reporting an average daily expenditure of 20 pesos with a range of 2 to 324 pesos. Households with multiple workers and other household members taking multiple transit trips form the long tail of households with high expenditures. Due to high proportions of unreported rents and household income, I include these households in the analysis with a dummy variable for whether the variable was not reported.

I matched households from the survey to 2005 census tracts, a national municipal database (INEGI, 2012), and transportation infrastructure from the National Statistics and Geography Agency (INEGI, 2013), the Secretary of Transportation and Highways (SETRAVI, 2013), and OpenStreetMap (2015) to estimate local population and job densities, accessibility measures, and network distance from metro stations, and the central Zocalo-Mexico City's historical, geographical, and political center. The following paragraph summarizes the remaining predictor variables from Table 1. Additional information

\footnotetext{
${ }^{2}$ I conduct the analysis on a random sample of the data to conduct final tests of model fits without overfitting to the data.
} 
on variable construction is available in Guerra (2014). ${ }^{3}$

Population density measures the total number of people in a household's home census tract divided by the area of the census tract in 2005 and is closest to a measure of gross residential density at the neighborhood level. Job density measures the total number of estimated jobs from the household travel survey in a household's municipality, divided by the sum of the land area of all urban census tracts within the municipality. This allows for the inclusion of informal employment, which is not included in the firm-based Economic Census, but according to estimates by Suárez, Murata, and Delgado (2016) accounts for $57 \%$ of all jobs. Destination diversity, a proxy for land-use diversity, ranges from zero, when destinations in a neighborhood are only in one category, to one, when there is an equal number of destinations in each category (for calculation and use, see Bhat \& Gossen, 2004; Guerra, 2014; Rajamani, Bhat, Handy, Knaap, \& Song, 2003; Zegras, 2010). Intersection density measures the number of road intersections in a neighborhood. Neighborhoods with more intersections per hectare are likely to be more walkable and at a more human scale. Two thirds of households owned their homes and reported estimated, rather than actual, monthly rents. The last variables in the table indicate the length the first three household workers' commutes in kilometers and whether the trip went to one of the ten more central boroughs of the Federal District that are best served by the metro (the urban center and first urban ring as reported in Guerra, 2015b; Suárez \& Delgado, 2007).

\subsection{Model forms and specifications}

Given a vector of predictor variables $(x)$, a household's expected transit expenditures $(y)$ are equal to the probability that the household $(i)$ uses transit multiplied by the expected expenditure given that household uses transit at all (Equation 1).

$$
E\left(y_{\mathrm{i}} \mid x_{\mathrm{i}}\right)=\operatorname{Pr}\left(y_{i}>0 \mid x_{i}\right)^{\star} E\left(y_{i} \mid x_{i}, y_{i}>0\right)
$$

I use a binomial logit model to estimate the probability that a given household spends any money on transit and ordinary least squares (OLS) to estimate how much households spend on transit given positive transit expenditure. The final reported OLS models predict the natural-log-transformation of positive household transit expenditures due to the long tail of high transit expenditures. This produced better model fits and more convincingly homoscedastic residual plots.

Transportation researchers frequently use Tobit or Heckman selection models to estimate joint discrete-continuous distributions such as mode choice and distance traveled (Golob \& van Wissen, 1989; Schwanen \& Mokhtarian, 2005) mode choice and vehicle travel (Chatman, 2003), the ratio of walk and transit trips to drive trips (Greenwald, 2003), distances walked (Boarnet, Greenwald, \& McMillan, 2008), vehicle travel (Guerra, 2014), and fuel choice and vehicle travel (van Wissen \& Golob, 1992). I prefer to estimate the two separate models, report these, and combine them using an additional simulation procedure. This allows for flexibility in the relationship between predictor variables and transit expenditures (i.e., higher income might relate to a lower probability of using transit but higher transit expenditures). The two separate models also provide better model fits on the test data (the random sample set aside from the original data) and produce more straightforward elasticity estimates when compared to a Tobit model (provided for reference in Appendix B).

To generate elasticity estimates, I use sample enumeration and report the average behavioral response of all households to account for non-linearity in the logit model and several predictor variables (for an overview of sample enumeration, see Ben-Akiva \& Lerman, 1985; Train, 2009). To capture the uncertainty from both the logit and OLS models, I bootstrap 4000 sample-enumerated elasticity estimates, weight these by the original survey expansion factors, and report the mean elasticity and $95 \%$

${ }^{3}$ I also tested a gravity based accessibility metric with a range of decay functions between 0.025 and 0.4 . The final models report the simpler metrics of municipal job density, distance to the Zocalo, and distance to metro stations, since these are more directly interpretable and fit the data better using 10-fold cross-validation. 
confidence interval. ${ }^{4}$ Figure 5 uses a similar procedure, but changes predictor variables to the percentile reported on the $\mathrm{x}$-axis, as opposed to making marginal changes to predictor variables.

Given the lack of data on preferences and the lack of suitable instrument variables, this estimation strategy does not account for residential self-selection, other than through socioeconomic controls. Residential self-selection can lead to biased parameter estimates by failing to account for households choosing to live in the neighborhoods that are best suited to their preferences (for an overview of the issue, see Brownstone, 2008; Brownstone \& Golob, 2009; Cao, Mokhtarian, \& Handy, 2009; Mokhtarian \& Cao, 2008). However, an unsuitable instrument or poorly specified structural equation model can bias parameter estimates substantially and erratically.

If self-selection biases the findings, it likely diminishes rather than strengthens the effects found. This is because a household with a preference for transit is likely to select into a transit-friendly environment, where transit use is high but costs are low. In neighborhoods where transit supply is poor, this transit-preferring household would typically spend even more on transit than a similar household that dislikes transit.

While the assumption is not testable given the available data, there are three primary reasons that residential self-selection is less likely to bias estimates related to household transit expenditures in a place like Mexico City than in cities in the United States. First, transit is the dominant form of transportation in Mexico City and self-selection is more likely to be an issue when the number of users is small. In the United States, for example, researchers do not worry as much about households selecting into car-friendly neighborhoods as those selecting into pedestrian or transit friendly neighborhoods. Second, only the wealthiest households have substantial control over where they live in Mexico City. They choose to live in central locations with high transit accessibility and diverse land uses, but drive (Guerra, 2014, 2015a). Transit use is actually higher in less accessible areas than more accessible areas, suggesting limited ability for transit users to select residential locations based on preference. Third, transit service is ubiquitous. While the metro may be faster and less expensive than minivans or minibuses, the entire metropolitan area is accessible by transit. This is very different from US cities in particular, where suburban locations often have extremely poor levels of transit accessibility unless close to a commuter rail station- thus resulting in US suburban transit users choosing to live near transit stations.

\subsection{Additional controls}

In addition to the primary reported models (Models $1 \& 4$ ), I also report models with potentially endogenous control variables. The second set of models (Models $2 \& 5$ ) includes controls for monthly rents and whether a household owns a private vehicle. Each of these variables almost certainly correlates with urban form and transit expenditures. However, vehicle ownership is strongly associated with modal preferences and thus likely diminishes the effect of urban form on household transit expenditures. Similarly, including monthly rent will tend to diminish the effect of urban form, particularly proximity to downtown and to the metro, since these are strongly associated with land values. Rents, however, are largely determined by transportation costs, including transit expenditures.

The third set of models (Models $3 \& 6$ ) includes additional controls on the work trips made by up to three household members. Commutes represent approximately half of all reported trips and their destinations are far less discretionary than other trips. While the emphasis of this study is on residential location, trip destination and length also play an important role in transit expenditures. However, like rent and vehicle ownership, they are endogenous to household location decisions. Household members choose their job locations based at least in part on where they live. Nevertheless, the additional two sets of models provide insights into the nature of the relationship between the built environment and transit expenditures. For example, if including commute distances does not diminish the effect of the built en-

${ }^{4}$ I also estimated elasticities using 2,000 bootstraps, which produced identical mean elasticity estimates to the second decimal place. 
vironment on transit expenditures, then this relationship is independent of the length of trips, and thus more likely related to mode choice or the number of trips taken.

\section{The relationship between urban form and household transit expenditures}

As expected, measures of urban form and household transit expenditures are statistically related in Mexico City. These relationships are robust to the inclusion of a range of household controls and, in some cases, also to estimated rent, car ownership, and commute destinations. Table 2 presents the results of the logit models predicting whether households spend any money on transit and the OLS models of household expenditures for the $80 \%$ of households that used transit. Models $2 \& 5$ include estimated rents and vehicle ownership variables, while Models 3 and 6 also include information on household members' commutes. In addition to the overall finding that urban form likely influences household transit expenditures, I discuss four overarching findings about the relationship between measures of the built environment and household transit expenditures in Mexico City.

Table 2: Binomial logit and OLS models of household transit expenditures

\begin{tabular}{|c|c|c|c|c|c|c|}
\hline & \multicolumn{6}{|c|}{ Dependent variable: } \\
\hline & \multirow{2}{*}{\multicolumn{3}{|c|}{$\begin{array}{c}\text { Public transit use }>0 \\
\text { Logit models }\end{array}$}} & \multicolumn{3}{|c|}{ Public transit expenditures $(\log )$} \\
\hline & & & & & OLS models & \\
\hline & $(1)$ & $(2)$ & (3) & $(4)$ & (5) & $(6)$ \\
\hline \multicolumn{7}{|c|}{ Urban form predictor variables } \\
\hline Kilometers to Metro & $\begin{array}{c}0.015^{*} \\
(0.009)\end{array}$ & $\begin{array}{l}-0.005 \\
(0.010)\end{array}$ & $\begin{array}{l}-0.005 \\
(0.010)\end{array}$ & $\begin{array}{c}0.045^{* * *} \\
(0.003)\end{array}$ & $\begin{array}{c}0.044^{* * *} \\
(0.003)\end{array}$ & $\begin{array}{c}0.042^{* * *} \\
(0.003)\end{array}$ \\
\hline Kilometers to Metro (squared) & $\begin{array}{c}-0.002^{* * *} \\
(0.000)\end{array}$ & $\begin{array}{c}-0.0003 \\
(0.000)\end{array}$ & $\begin{array}{l}0.0002 \\
(0.000)\end{array}$ & $\begin{array}{c}-0.001^{* * *} \\
(0.000)\end{array}$ & $\begin{array}{c}-0.001^{* * *} \\
(0.000)\end{array}$ & $\begin{array}{c}-0.001^{* * *} \\
(0.000)\end{array}$ \\
\hline Kilometers to Zocalo & $\begin{array}{c}-0.049^{* * *} \\
(0.011)\end{array}$ & $\begin{array}{l}-0.015 \\
(0.011)\end{array}$ & $\begin{array}{l}-0.016 \\
(0.011)\end{array}$ & $\begin{array}{c}0.012^{* * *} \\
(0.003)\end{array}$ & $\begin{array}{c}0.013^{* * *} \\
(0.003)\end{array}$ & $\begin{array}{c}0.006^{* *} \\
(0.003)\end{array}$ \\
\hline Kilometers to Zocalo (squared) & $\begin{array}{c}0.002^{* * *} \\
(0.000)\end{array}$ & $\begin{array}{c}0.001^{* *} \\
(0.000)\end{array}$ & $\begin{array}{l}0.0003 \\
(0.000)\end{array}$ & $\begin{array}{c}-0.0002^{* *} \\
(0.000)\end{array}$ & $\begin{array}{c}-0.0002^{* * *} \\
(0.000)\end{array}$ & $\begin{array}{c}-0.0003^{* * *} \\
(0.000)\end{array}$ \\
\hline Jobs per hectare & $\begin{array}{c}-0.001^{* * *} \\
(0.001)\end{array}$ & $\begin{array}{l}-0.001 \\
(0.001)\end{array}$ & $\begin{array}{c}-0.0003 \\
(0.001)\end{array}$ & $\begin{array}{c}-0.001^{* * *} \\
(0.000)\end{array}$ & $\begin{array}{c}-0.001^{* * *} \\
(0.000)\end{array}$ & $\begin{array}{c}-0.001^{* * *} \\
(0.000)\end{array}$ \\
\hline People per hectare & $\begin{array}{c}0.004^{* * *} \\
(0.000)\end{array}$ & $\begin{array}{c}0.002^{* * *} \\
(0.000)\end{array}$ & $\begin{array}{c}0.002^{* * *} \\
(0.000)\end{array}$ & $\begin{array}{c}0.0003^{* * *} \\
(0.000)\end{array}$ & $\begin{array}{c}0.0002^{* * *} \\
(0.000)\end{array}$ & $\begin{array}{c}0.0001^{*} \\
(0.000)\end{array}$ \\
\hline Destination diversity & $\begin{array}{c}-0.005^{* * *} \\
(0.001)\end{array}$ & $\begin{array}{c}-0.003^{* * *} \\
(0.001)\end{array}$ & $\begin{array}{c}-0.002^{* *} \\
(0.001)\end{array}$ & $\begin{array}{c}-0.004^{* * *} \\
(0.000)\end{array}$ & $\begin{array}{c}-0.003^{* * *} \\
(0.000)\end{array}$ & $\begin{array}{c}-0.003^{* * *} \\
(0.000)\end{array}$ \\
\hline Intersections per hectare & $\begin{array}{c}0.01 \\
(0.012) \\
\end{array}$ & $\begin{array}{c}0.017 \\
(0.013) \\
\end{array}$ & $\begin{array}{c}0.017 \\
(0.013)\end{array}$ & $\begin{array}{c}0.009^{* * *} \\
(0.003)\end{array}$ & $\begin{array}{c}0.009^{* * *} \\
(0.003)\end{array}$ & $\begin{array}{c}0.012^{* * *} \\
(0.003)\end{array}$ \\
\hline \multicolumn{7}{|c|}{ Socioeconomic predictor variables } \\
\hline Monthly income (nat. log) & $\begin{array}{c}-0.708^{* * *} \\
(0.021)\end{array}$ & $\begin{array}{c}-0.273^{* * *} \\
(0.024)\end{array}$ & $\begin{array}{c}-0.346^{* * *} \\
(0.024)\end{array}$ & $\begin{array}{c}0.009 \\
(0.007)\end{array}$ & $\begin{array}{c}0.029^{* * *} \\
(0.007)\end{array}$ & $\begin{array}{l}-0.011 \\
(0.007)\end{array}$ \\
\hline Income missing & $\begin{array}{c}-6.898^{* * *} \\
(0.199)\end{array}$ & $\begin{array}{c}-2.862^{* * *} \\
(0.222)\end{array}$ & $\begin{array}{c}-3.525^{* * *} \\
(0.226)\end{array}$ & $\begin{array}{c}0.041 \\
(0.063)\end{array}$ & $\begin{array}{c}0.223^{* * *} \\
(0.066)\end{array}$ & $\begin{array}{c}-0.129^{* *} \\
(0.063)\end{array}$ \\
\hline People over 6 & $\begin{array}{c}0.202^{* * *} \\
(0.011)\end{array}$ & $\begin{array}{c}0.197^{* * *} \\
(0.011)\end{array}$ & $\begin{array}{c}0.219^{* * *} \\
(0.012)\end{array}$ & $\begin{array}{c}0.044^{* * *} \\
(0.003)\end{array}$ & $\begin{array}{c}0.044^{* * *} \\
(0.003)\end{array}$ & $\begin{array}{c}0.051^{* * *} \\
(0.003)\end{array}$ \\
\hline People 6 or under & $\begin{array}{c}-0.196^{* * *} \\
(0.022)\end{array}$ & $\begin{array}{c}-0.266^{* * *} \\
(0.023)\end{array}$ & $\begin{array}{c}-0.269^{* * *} \\
(0.024)\end{array}$ & $\begin{array}{c}-0.074^{* * *} \\
(0.006)\end{array}$ & $\begin{array}{c}-0.077^{* * *} \\
(0.006)\end{array}$ & $\begin{array}{c}-0.075^{* * *} \\
(0.006)\end{array}$ \\
\hline Workers & $\begin{array}{c}0.292^{* * *} \\
(0.019)\end{array}$ & $\begin{array}{c}0.296^{* * *} \\
(0.020)\end{array}$ & $\begin{array}{c}0.121^{* * *} \\
(0.022)\end{array}$ & $\begin{array}{c}0.137^{* * *} \\
(0.005)\end{array}$ & $\begin{array}{c}0.138^{* * *} \\
(0.005)\end{array}$ & $\begin{array}{c}0.066^{* * *} \\
(0.005)\end{array}$ \\
\hline Average age of adults & $\begin{array}{c}0.008 \\
(0.015)\end{array}$ & $\begin{array}{c}0.090^{* * *} \\
(0.016)\end{array}$ & $\begin{array}{c}0.073^{* * *} \\
(0.016)\end{array}$ & $\begin{array}{c}0.044^{* * *} \\
(0.005)\end{array}$ & $\begin{array}{c}0.047^{* * *} \\
(0.005)\end{array}$ & $\begin{array}{c}0.040^{* * *} \\
(0.004)\end{array}$ \\
\hline Average age (squared) & $\begin{array}{c}-0.0003 \\
(0.000) \\
\end{array}$ & $\begin{array}{c}-0.001^{* * *} \\
(0.000)\end{array}$ & $\begin{array}{c}-0.001^{* * *} \\
(0.000)\end{array}$ & $\begin{array}{c}-0.001^{* * *} \\
(0.000)\end{array}$ & $\begin{array}{c}-0.001^{* * *} \\
(0.000)\end{array}$ & $\begin{array}{c}-0.001^{* * *} \\
(0.000)\end{array}$ \\
\hline
\end{tabular}


Table 2: Binomial logit and OLS models of household transit expenditures (continued)

\begin{tabular}{|c|c|c|c|c|c|c|}
\hline \multicolumn{7}{|c|}{ Endogenous control variables } \\
\hline Has a vehicle & - & $\begin{array}{c}-1.733^{* * *} \\
(0.039)\end{array}$ & $\begin{array}{c}-1.790^{* * *} \\
(0.039)\end{array}$ & - & $\begin{array}{c}-0.129^{* * *} \\
(0.010)\end{array}$ & $\begin{array}{c}-0.146^{\text {*** }} \\
(0.009)\end{array}$ \\
\hline Monthly estimated rent (nat. $\log$ ) & - & $\begin{array}{c}-0.358^{* * *} \\
(0.025)\end{array}$ & $\begin{array}{c}-0.363^{* * *} \\
(0.025)\end{array}$ & - & $\begin{array}{c}0.01 \\
(0.008)\end{array}$ & $\begin{array}{c}0.006 \\
(0.007)\end{array}$ \\
\hline Rent missing & - & $\begin{array}{c}-2.873^{* * *} \\
(0.193)\end{array}$ & $\begin{array}{c}-2.984^{* * *} \\
(0.195)\end{array}$ & - & $\begin{array}{l}0.123^{* *} \\
(0.056)\end{array}$ & $\begin{array}{c}0.07 \\
(0.053) \\
\end{array}$ \\
\hline \multicolumn{7}{|c|}{ Commute trip characteristics } \\
\hline Worker 1: central destination & - & & $\begin{array}{c}0.079^{* *} \\
(0.039)\end{array}$ & - & - & $\begin{array}{c}-0.100^{\text {*** }} \\
(0.010)\end{array}$ \\
\hline Worker 2: central destination & - & & $\begin{array}{c}0.255^{* * *} \\
(0.068)\end{array}$ & - & - & $\begin{array}{c}0.067^{* * *} \\
(0.016)\end{array}$ \\
\hline Worker 3: central destination & - & & $\begin{array}{l}0.177^{*} \\
(0.102)\end{array}$ & - & - & $\begin{array}{c}0.011 \\
(0.023)\end{array}$ \\
\hline Worker 1: commute distance $(\mathrm{km})$ & - & & $\begin{array}{c}0.032^{* * *} \\
(0.002)\end{array}$ & - & - & $\begin{array}{c}0.018^{* * *} \\
(0.001)\end{array}$ \\
\hline Worker 2: commute distance $(\mathrm{km})$ & - & & $\begin{array}{c}0.033^{* * *} \\
(0.004)\end{array}$ & - & - & $\begin{array}{c}0.018^{* * *} \\
(0.001)\end{array}$ \\
\hline Worker 3: commute distance $(\mathrm{km})$ & - & & $\begin{array}{c}0.006 \\
(0.007)\end{array}$ & - & - & $\begin{array}{c}0.004^{* * *} \\
(0.001)\end{array}$ \\
\hline Constant & $\begin{array}{c}6.630^{* * *} \\
(0.340)\end{array}$ & $\begin{array}{c}4.803^{* * *} \\
(0.380)\end{array}$ & $\begin{array}{c}5.669^{* * * *} \\
(0.388)\end{array}$ & $\begin{array}{c}1.423^{* * *} \\
(0.105)\end{array}$ & $\begin{array}{c}1.157^{* * *} \\
(0.113)\end{array}$ & $\begin{array}{c}1.703^{* * *} \\
(0.107)\end{array}$ \\
\hline Observations & 31,167 & 31,167 & 31,167 & 24,911 & 24,911 & 24,911 \\
\hline McFadden R2 & 0.103 & 0.200 & 0.223 & 0.189 & 0.195 & 0.281 \\
\hline Log Likelihood & $-14,021$ & $-12,495$ & $-12,145$ & $-26,821$ & $-26,730$ & $-25,323$ \\
\hline
\end{tabular}

Notes: Standard errors in parentheses, ${ }^{*} \mathrm{p}<0.1 ;{ }^{* *} \mathrm{p}<0.05 ;{ }^{* * *} \mathrm{p}<0.01$

\subsection{Small and inconsistent relationships with whether households use transit at all}

Local measures of urban form have small and somewhat inconsistent correlations with whether a household spends any money on transit. As expected, households living in densely populated neighborhoods are more likely to have members using transit. Households in diverse neighborhoods, by contrast, are less likely to use transit. This may be because households in neighborhoods with diverse land uses can accomplish more daily activities without going as far and by non-motorized modes, particularly walking. This may also be because wealthy households are more likely to drive and tend to live in neighborhoods with local shops and other amenities (Guerra, 2014, 2015b). Intersection density is not statistically associated with transit use in any of the three logit models (Models 1, 2, \& 3).

Regional measures, such as a household's distance to downtown, are even more weakly associated than local measures with whether a household uses transit at all. The inclusion of estimated rents and vehicle ownerships weakens this relationship further, generally to the point of not being statistically different from zero. In the case of distance to the downtown, more central households are more likely to be among the fifth of households that did not use transit. This may relate to the greater ease of walking and biking in these neighborhoods. However, given the weakness of the relationships combined with their insignificance when including rent and vehicle ownership, regional household location appears to be less related to whether a household uses transit than local measures like population density and destination diversity.

The strongest predictors of whether a household is among the $80 \%$ of households that spent mon- 
ey on transit during the survey day are a household's income and composition. A standard deviation increase in the natural log of income has a stronger association with transit use than a one standard deviation increase in all six measures of the built environment combined (Appendix A). Including vehicle ownership substantially weakens the predictive power of income, but doubles the model's predictive power. In short, the best predictors of whether a household is among the fifth of households that did not use transit at all is whether the household is wealthy and whether it has chosen to buy a car.

\subsection{Stronger relative correlation with total expenditures}

For the $80 \%$ of households that used transit at least once, by contrast, the relationship between the built environment and total household transit expenditures is substantially stronger, both absolutely and relative to household composition and income. Job density, population density, destination diversity, intersection density, distance to the downtown, and distance to the metro are generally as strongly, or more strongly, correlated with the amount of money spent on transit as measures of income or household structure. However, overall transit expenditures are higher, not lower, in densely populated areas with pedestrian friendly environments. As stated in the research design, this may relate to households using more transit in places with higher quality transit service. Households in neighborhoods with more diverse destination spend less money on transit, as well as being less likely to use transit at all.

For the fifth of households that did not use transit on a given weekday the built environment appears to play only a small role in that decision. For the four fifths that did, however, the built environment has an important relationship with how much the household spends. Put another way, a poor household relies on transit regardless of location, but the amount that the household must spend to accomplish its daily activities varies substantially with location and neighborhood form. Similarly, a wealthy household may never use transit, despite living in a highly transit-accessible neighborhood.

\subsection{Neighborhood form matters, but the relationship is complex}

Neighborhood measures of urban form do not have consistent relationships with household transit expenditures. In densely populated neighborhoods, households are more likely to use transit and tend to spend more on transit than households in less densely populated neighborhoods. This may relate to dense neighborhoods having better transit supply or to the lower probability of driving in densely populated neighborhoods due to congestion and parking constraints. In neighborhoods with diverse destinations, households are less likely to use transit and also spend less when they do. Street network density is associated with higher transit expenditures but not with the probability that households use transit at all. As stated in the research design, more transit-friendly built environments could both lower or increase transit expenses.

From a public policy perspective, moreover, higher transit expenditures are not necessarily undesirable. More trips represent more economic and social activity. More trips by transit, instead of cars, likely mean less pollution, fewer traffic fatalities, and less congestion per trip. The complexity of the relationship between local measures of urban form and transit expenditures, however, suggests that changes to neighborhood design and local planning may not be the most effective way to reduce household transit expenditures in Mexico City. Reducing neighborhood density, for example, would likely reduce transit expenditures, but not in a way that is socially desirable. By contrast, increasing the diversity of activities through mixed land uses would likely encourage shorter, less expensive transit trips, as well as more walking and biking. 


\subsection{Regional location and transit accessibility matter}

The relationship between regional location and household transit expenditures is more straightforward: distance to metro stations and the urban center correlate with how much households spend on transit but less so with whether they use transit. The quadratic term indicates that transit expenditures tend to increase for all but the most peripherally located households (60 kilometers from the center). Presumably the cost and inconvenience of transit in the far periphery leads households to travel less, drive, or choose destinations closer to home. However, just a fraction of a percent of households lives 60 kilometers or more from the center. Transit expenditures also increase with distance to the metro out to $45 \mathrm{ki}$ lometers - further than the farthest metropolitan household lives from a station. Reducing households' distance to transit and the urban center would tend to maintain or increase transit use, but reduce the long multimodal transit trips that consume so much of so many suburban households' time and money.

The relationship between geographic location and household transit expenditures is also fairly strong. Households' distance from the metro and the downtown are the best predictors of how much the $80 \%$ of transit-using households spend on transit, despite being highly correlated outside of the Federal District where metro service is sparse. ${ }^{5}$ Figure 4, which maps the mean estimated transit expenses for a typical household in the region while controlling for household income and composition, shows the importance of a household's location within the region in determining transit expenditures. Including commute characteristics halves the strength of relationship between distance to the center and transit expenditures. Longer commutes, taken more frequently by those in the periphery, are associated with a higher probability of transit use (Model 3) and higher transit expenditures (Model 6).

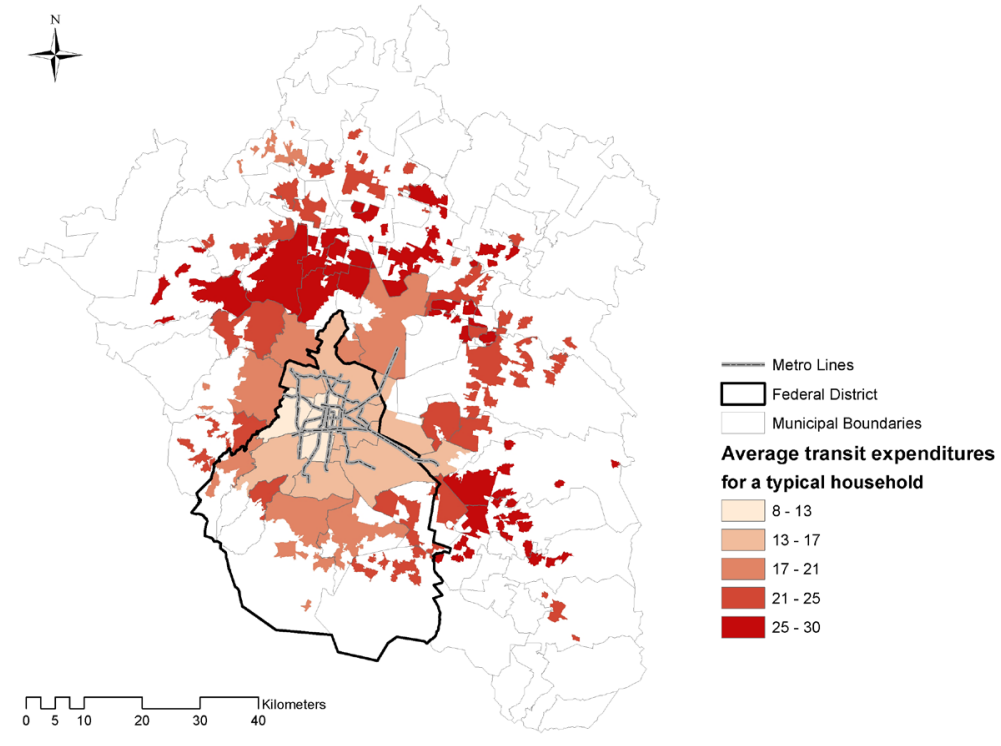

Figure 4: Mean predicted transit expenditure by municipality for a typical household

Source: Compiled by author from state, municipal, and locality boundary files from the Instituto Nacional de Estadística y Geografía (INEGI, 2013) and calculations from the 2007 household travel survey using Models $1 \& 4$ from Table 2 with all socioeconomic variables set to the median value (INEGI, 2007).

The relationship between transit expenditures and a household's distance from the city center and the metro is not just statistically significant, but economically significant. According to the model, halving the distance to the metro for suburban residents (from an average of 11 kilometers) would save con-

\footnotetext{
${ }^{5}$ Since distance to the metro and the center are strongly correlated, I tested the model for multicollinearity. Although the inclusion of both variables resulted in VIF scores well above five, ten-fold cross-validation indicated that including the two variables did not over-fit the data. I include both variables since they both have theoretically plausible relationships with transit expenditures and the combination fit the data better. Removing one of the two variables from the estimation increases the strength of the other as a predictor of household transit expenditures.
} 
sumers 6 million pesos per day. To put that number into perspective, the metro collected approximately 8 million pesos in fare revenues on the day of the survey. Using Parry and Strand's (2012) estimates of the external congestion costs of a vehicle mile of travel in Santiago de Chile-a city with similar household income levels (Zegras, 2010) — this amounts to just under the total external congestion costs of suburban households' 13 million average daily VMT (author's calculation using INEGI, 2007; Parry $\&$ Strand, 2012). ${ }^{6}$

\subsection{A note on socioeconomic and other control variables}

Although not the focus of this paper, household composition and income also have important relationships with whether and how much households spend on transit. More workers and more household members increase the amount of transit expenditures. ${ }^{7}$ The number of children under 6 has a negative correlation, presumably because having more children increases the probability of driving (Guerra, 2014) and may also reduce the total amount of household travel per person. While the probability of using transit decreases with higher income, wealthier households that do use transit tend to spend more on transit - though the relationship is only statistically significant in Model 5. This provides some supportive evidence for Crôtte, Noland, and Graham's (2009) finding that the metro is a normal good for most households, but an inferior good for the wealthiest.

As expected, vehicle ownership is associated with lower transit use and lower transit expenditures. It also adds as much predictive power to Model 3 as all the other variables combined. This suggests that the $20 \%$ of households that do not use transit rely substantially on cars. Estimated monthly rent decreases with transit expenditures, as households substitute rent and accessibility. However, the relationship is weaker than might be expected and is not statistically associated with the amount of transit expenditures (Models $5 \& 6$ ). The weakness of this relationship may occur for a variety of reasons. First, the survey does not include any information on housing size, quality, neighborhood amenities, or other factors that relate to housing values. Second, households probably have limited options to substitute lower transit costs for higher rents or to choose work places closer to residences.

\subsection{Elasticity of household transit expenditures with respect to the built environment}

In order to compare the results of the analysis with existing and future studies, Table 3 presents the estimated elasticity of each measure of urban form with respect to total household transit expenditures, using Models 1 and 4. For ease of interpretation, the table provides mean elasticities, standard deviations, and $95 \%$ confidence intervals from the bootstrapped sample enumeration. The mean elasticities - which range from 0.02 to 0.18 in absolute value - are within the range of estimates in Ewing and Cervero's (2010) meta-analysis of studies looking at urban form, vehicle travel, and mode choice. While these relationships are inelastic, distance to the downtown, population density, and destination diversity are just as strongly correlated with total household transit expenditures as income or other control variables. This reinforces the finding that urban form plays a substantial role in household transportation expenditures.

\footnotetext{
${ }^{6}$ Parry and Strand estimate a total congestion externality of $\$ 0.04$ per mile. I convert this number first to 2007 dollars and then to 2007 pesos per kilometer.

${ }^{7}$ Despite some non-linearity in the relationships, I enter the number of workers and household members into the model as continuous variables instead of factors. This conserves significant space in the final reported model, results in nearly identical model fits, and does not influence the estimated relationship between the measures of urban form and transit expenditures.
} 
Table 3: Expected percent change in household transit expenditures from a 1\% increase in measures of urban form and income

\begin{tabular}{|l|c|c|c|c|c|}
\hline Statistic & Mean & St. Dev. & \multicolumn{3}{|c|}{$\begin{array}{c}\text { 95\% confidence } \\
\text { interval }\end{array}$} \\
\hline Distance to the metro & 0.08 & 0.02 & 0.04 & - & 0.11 \\
\hline Distance to Zocalo & 0.18 & 0.03 & 0.11 & - & 0.25 \\
\hline Population density & 0.15 & 0.01 & 0.13 & - & 0.18 \\
\hline Job density & -0.06 & 0.01 & -0.07 & - & -0.04 \\
\hline Destination diversity & -0.13 & 0.01 & -0.15 & - & -0.11 \\
\hline Intersections per hectare & 0.02 & 0.01 & 0.01 & - & 0.04 \\
\hline Household income & -0.12 & 0.01 & -0.13 & - & -0.10 \\
\hline
\end{tabular}

Figure 5 plots the mean expected transit expenditure for all households with each variable in Table 3 individually set to the $5^{\text {th }}$ to $95^{\text {th }}$ percentile on the $x$-axis (again using the preferred Models $1 \& 4$ ). If all households lived 4 kilometers from the metro (the $50^{\text {th }}$ percentile value), the models predict a mean expenditure of 14.8 pesos, compared to 17.7 if all households lived 9 kilometers away (the $75^{\text {th }}$ percentile). Note that the mean transit expenditure is closer to the actual median expenditure on account of the log-transformed dependent variable. In addition to showing how each measure of urban form is related to transit expenditures while controlling for the other variables, the plots also reveal some of the underlying structure of this relationship. For example, since jobs are so clustered in a few central municipalities, mean transit expenditures drop substantially at around the $80^{\text {th }}$ percentile of job density (50 jobs per hectare). Household income and population density, by contrast, have fairly steady relationships with transit expenditures within the $5^{\text {th }}$ and $95^{\text {th }}$ percentiles of the data. The plots also reveal that distance to transit is more strongly related to transit expenditures than the elasticity reported in Table 2 . This is largely due to the quadratic terms in Models $1 \& 4$, which together predict substantial decreases in transit expenditures beyond the $95^{\text {th }}$ percentile distance and reduce the sample-enumerated mean elasticity. 

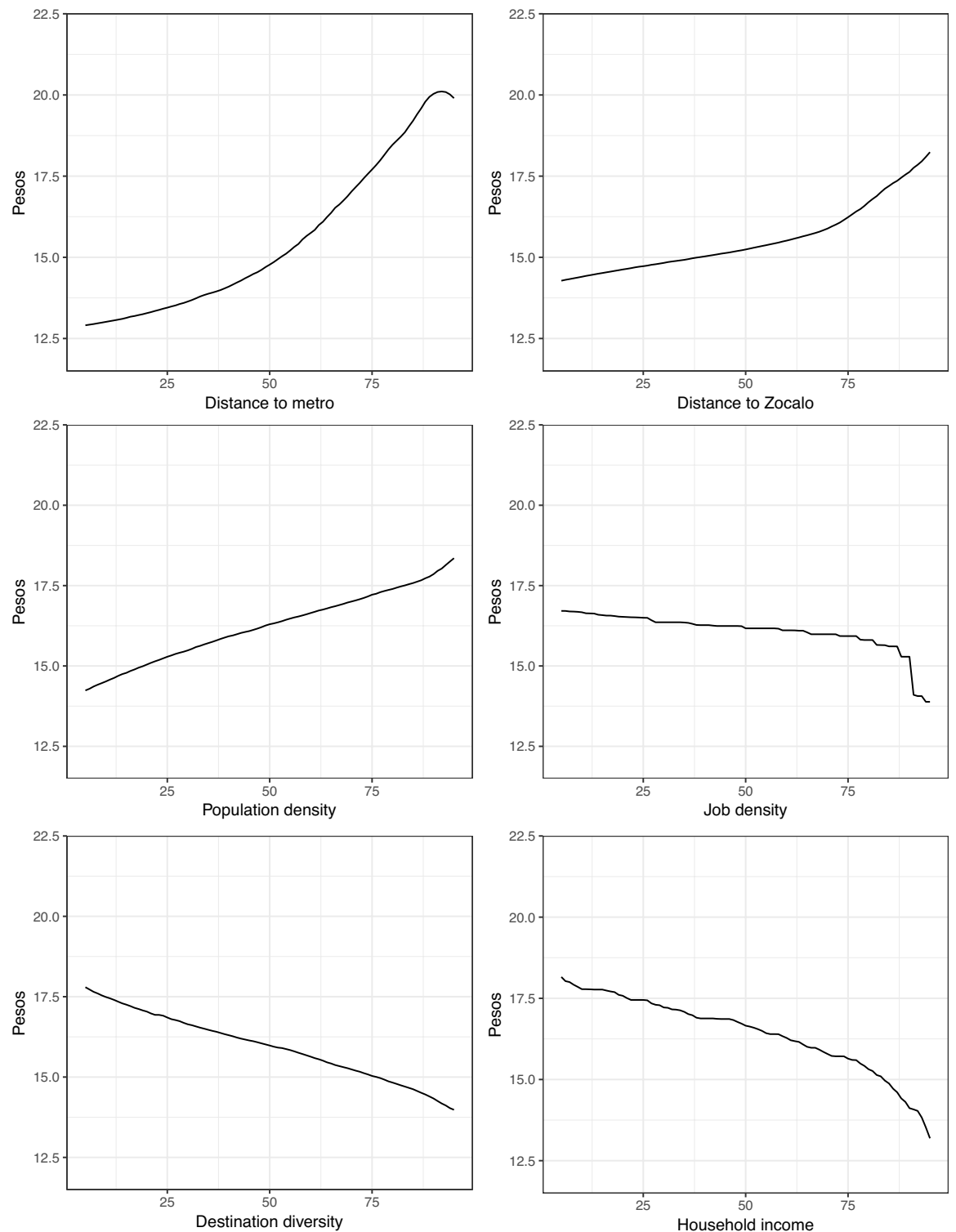

Figure 5: Predicted mean transit expenditures (95\% confidence intervals shaded in gray) for all households against the percentile value for predictor variable

\section{$5 \quad$ Conclusions}

I began this article with a description of one of Mexico City's many long and expensive daily transit commutes. Although price is a common input into behavioral and predictive models of travel behavior, it rarely features as an outcome of interest. Yet the relationship between Mexico City's transit supply and urban form contributes significantly and substantially to the metropolitan area's notoriously long commutes and the high share of income that many poor households spend on transit. Household transit expenditures vary systematically with neighborhood and regional measures of urban form. These relationships are complex and nonlinear but robust to the inclusion of households' income, rent, size, and structure. Although inelastic, the relationships are also relatively strong: job density, distance to the 
metro, and population density correlate as strongly with transit expenditures as household income and rent.

More precisely, the built environment appears to influence how much households spend on transit more than whether they use transit at all. Households that live far from the metro are as likely or more likely to use transit as similar households that live close to the metro (Figure 6), but spend substantially more money on transit. Like Marta, they rely on multiple paid transfers on a variety of privately and publicly operated transit lines. Since the most transit-accessible neighborhoods are also the most caraccessible, households that do not use transit at all often select into some of the most transit accessible neighborhoods. This helps explain why transit use is higher in the State of Mexico than the much more transit-accessible Federal District. Poor-to-moderate-income households, in particular, must rely on transit but have less ability to move into the neighborhoods best served by the metro. Future research could shed additional light on the precise nature of the mechanisms by which the built environment influences transit expenditures and how considerations about transit costs influence households' residential location choices.

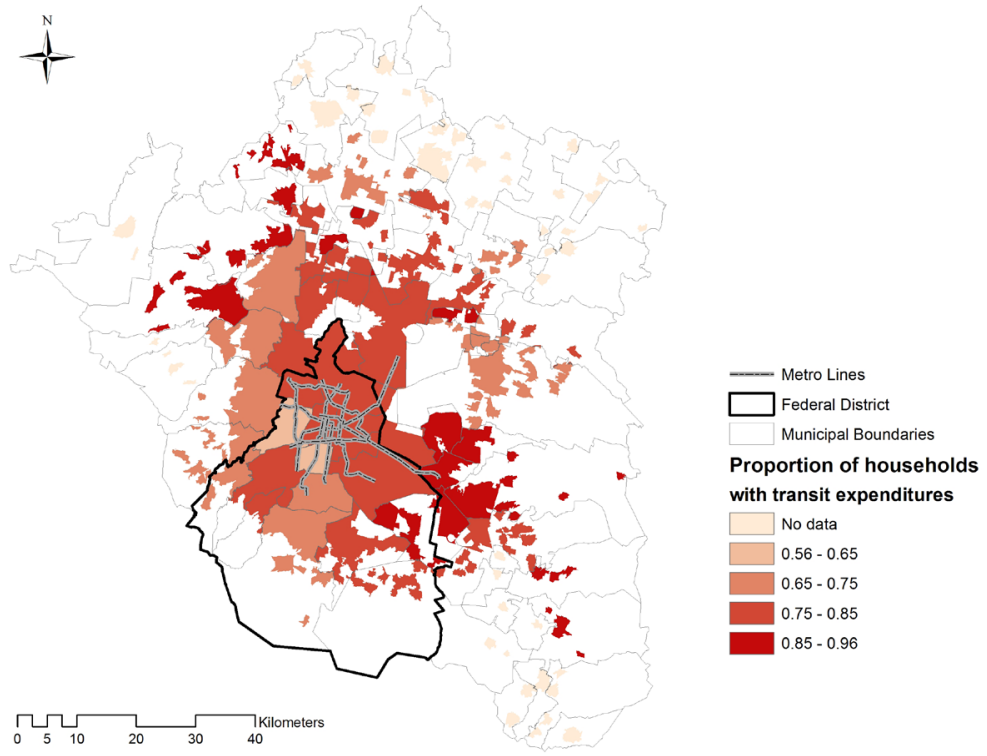

Figure 6: Percent of households that used transit by municipality on an average weekday in 2007

Source: Compiled by author from state, municipal, and locality boundary files from the Instituto Nacional de Estadística y Geografía (INEGI, 2013) and calculations from the 2007 household travel survey (INEGI, 2007).

\subsection{Policy conclusions}

I expand on the overall findings discussed in the previous section to draw three broad policy conclusions. First, changes in urban form and better integrated transportation have the potential to lead to substantial reductions in household transit expenditures, particularly for poor households that are least able to choose faster modes or move into more accessible neighborhoods. In Mexico City-where incomes are frequently low, transit use is high, and spatial socioeconomic segregation is common - urban form is as important a predictor of transit expenditures as household income or size. The dollar values involved in better integrating the metro system and housing production are in the ballpark of the total external congestion costs of suburban driving and total metro fare revenues. From a policy perspective, there is a clear social benefit to encouraging more centralized development near metro stations.

Second, because the potential dollar values are great, there may be an opportunity to save money by 
better integrating transportation and land-use planning, which frequently work at odds. For example, the Federal District government spends the lion's share of its transportation budget to subsidize the metro. The primary purpose of this policy is to make the metro more affordable for low- and moderateincome households. At the same time, Mexico's principal subsidized housing policy, which produces more new housing than the market and informal sector combined (for an overview, see Monkkonen, 2011), has concentrated low-to-medium income households in the exact types of locations predicted to have the highest transit expenses: high-density, single-use, peripheral neighborhoods with poor transit access and disconnected street networks (for a description, see Guerra, 2015a). There is a missed opportunity to coordinate and design new subsidized housing developments with new transit investments. As a result, population growth continues in areas with the worst transit accessibility, despite high transit use in fast-growing neighborhoods. There have been efforts to reform housing policies in the wake of the Great Recession, but there is not yet evidence of more centralized housing construction. Similarly, in an attempt to concentrate development in the urban center, the Federal District's Bando Dos policy, enacted at the end of 2000 and canceled in 2007, limited development in parts of the city proper outside of the four most central boroughs. A primary result, however, was to push newer housing development out in the suburbs, even further from downtown and the centralized metro system where transportation costs are highest (OECD, 2015).

Third and finally, to reduce transit expenditures and improve travel conditions for the most vulnerable transit users, there is a need for improved transit service into the existing suburbs. Distance to the metro-Mexico City's least expensive, safest, and fastest form of public transportation (Ward, 1998; Wirth, 1997) - is among the strongest predictors of household transit expenditures. In many of the world's low- and middle-income cities, suburban residents use transit as much or more than centrallylocated residents but usually have substantially worse access to metro, rail, or bus rapid transit. Policy makers generally favor the urban core when making new investments. Mexico City is no exception. The most notable transit policy of the last decade has been the construction of a new bus rapid transit network, which like the metro is a centralized system that provides only limited service into populous, dense, and transit-reliant suburban neighborhoods. While the bus rapid transit policy has other merits, it does not do enough for the millions of transit-using metropolitan residents of the State of Mexico. Finding ways to improve transit service outside of city centers remains one of the principal challenges of improving accessibility and quality of life for low-to-middle income residents of many of the world's large and fast-growing cities.

\section{Acknowledgments}

This analysis coincides with and draws in part from a study on housing and transportation affordability in Mexico City that was funded by the Organization for Economic Co-operation and Development. I am grateful for the helpful comments and suggestions of Dan Chatman, David Levinson, Eric Morris, and several anonymous reviewers. 


\section{References}

Alonso, W. (1960). A theory of the urban land market. Papers in Regional Science, 6(1), 149-157.

Alonso, W. (1964). Location and land use. Toward a general theory of land rent. Cambridge, MA: Harvard University Press.

Ben-Akiva, M., \& Lerman, S. (1985). Discrete choice analysis: Theory and application to travel demand (1st ed.). Cambridge, MA: The MIT Press.

Bhat, C. R., \& Gossen, R. (2004). A mixed multinomial logit model analysis of weekend recreational episode type choice. Transportation Research Part B: Methodological, 38(9), 767-787. doi.org/10.1016/j. trb.2003.10.003

Boarnet, M. (2006). About this issue: Planning's role in building healthy cities: An introduction to the special issue. Journal of the American Planning Association, 72(1), 5-9. doi. org/10.1080/01944360608976719

Boarnet, M. (2011). A broader context for land use and travel behavior, and a research agenda. Journal of the American Planning Association, 77(3), 197-213. doi.org/10.1080/01944363.2011.593483

Boarnet, M., Greenwald, M., \& McMillan, T. (2008). Walking, urban design, and health: Toward a cost-benefit analysis framework. Journal of Planning Education and Research, 27(3), 341-358. doi.org/10.1177/0739456X07311073

Brownstone, D. (2008). Key relationships between the built environment and VMT (Special Report No. 298). Washington, DC: Transportation Research Board. Retrieved from http://onlinepubs.trb.org/ Onlinepubs/sr/sr298brownstone.pdf

Brownstone, D., \& Golob, T. F. (2009). The impact of residential density on vehicle usage and energy consumption. Journal of Urban Economics, 65(1), 91-98. doi.org/10.1016/j.jue.2008.09.002

Brueckner, J. K. (1987). The structure of urban equilibria: A unified treatment of the Muth-Mills model. In E. S. Mills (Ed.), Handbook of regional and urban economics (pp. 821-845). New York: Elsevier.

Cao, X., Mokhtarian, P., \& Handy, S. (2009). Examining the impacts of residential self-selection on travel behavior: A focus on empirical findings. Transport Reviews, 29(3), 359-395. doi.org/10.1080/01441640802539195

Center for Neighborhood Technology. (n.d.). The H+T Affordability Index. Retrieved from http:// htaindex.cnt.org/

Cervero, R. (2007). Transit-oriented development's ridership bonus: A product of self-selection and public policies. Environment and Planning A, 39(9), 2068-2085. doi.org/10.1068/a38377

Chatman, D. (2003). How density and mixed uses at the workplace affect personal commercial travel and commute mode choice. Transportation Research Record, 1831(1), 193-201. doi.org/10.3141/183122

Crôtte, A., Graham, D., \& Noland, R. (2011). The role of metro fares, income, metro quality of service and fuel prices for sustainable transportation in Mexico City. International Journal of Sustainable Transportation, 5(1), 1-24. doi.org/10.1080/15568310903050073

Crôtte, A., Noland, R., \& Graham, D. (2009). Is the Mexico City metro an inferior good? Transport Policy, 16(1), 40-45. doi.org/10.1016/j.tranpol.2009.02.009

Davis, D. (1994). Urban leviathan: Mexico City in the twentieth century. Philadelphia: Temple University Press.

Ewing, R., Bartholomew, K., Winkelman, S., Walters, J., \& Chen, D. (2008). Growing cooler: The evidence on urban development and climate change. Washington, DC: Urban Land Institute.

Ewing, R., \& Cervero, R. (2001). Travel and the built environment: A synthesis. Transportation Research Record, 1780, 87-114. doi.org/10.3141/1780-10 
Ewing, R., \& Cervero, R. (2010). Travel and the built environment: A meta-analysis. Journal of the American Planning Association, 76(3), 265-294. doi.org/10.1080/01944361003766766

Glaeser, E., Kahn, M., \& Rappaport, J. (2008). Why do the poor live in cities? The role of public transportation. Journal of Urban Economics, 63(1), 1-24. doi.org/10.1016/j.jue.2006.12.004

Golob, T., \& van Wissen, L. (1989). A joint household travel distance generation and car ownership model. Transportation Research Part B: Methodological, 23(6), 471-491. doi.org/10.1016/01912615(89)90045-3

Greenwald, M. (2003). The road less traveled: New urbanist inducements to travel mode substitution for nonwork trips. Journal of Planning Education and Research, 23(1), 39-57. doi. org/10.1177/0739456X03256248

Guerra, E. (2014). The built environment and car use in Mexico City: Is the relationship changing over time? Journal of Planning Education and Research, 34(4), 394-408. doi. org/10.1177/0739456X14545170

Guerra, E. (2015a). Has Mexico City's shift to commercially produced housing increased car ownership and car use? Journal of Transport and Land Use, 8(2), 171-189.

Guerra, E. (2015b). The geography of car ownership in Mexico City: A joint model of households' residential location and car ownership decisions. Journal of Transport Geography, 43, 171-180. doi. org/10.1016/j.jtrangeo.2015.01.014

Guerra, E., \& Kirschen, M. (2016). Housing plus transportation affordability indices: Uses, opportunities, and challenges. Technical paper for OECD round-table on income inequality, social inclusion, and mobility. Paris: Organization for Economic Co-operation and Development.

INEGI. (2007). Encuesta Origen-Destino de los Viajes de los Residentes de la Zona Metropolitana del Valle de México 2007. Mexico City: Instituto Nacional de Estadística, Geografía e Informática.

INEGI. (2012). Sistema Estatal y Municipal de Bases de Datos. Retrieved from http://sc.inegi.org.mx/ sistemas/cobdem/

INEGI. (2013). Instituto Nacional de Estadística y Geografía. Retrieved from http://www.inegi.org. $\mathrm{mx} /$

INEGI. (2015). Encuesta Intercensal. 2015. Retrieved from http://www.inegi.org.mx/est/contenidos/ Proyectos/encuestas/hogares/especiales/ei2015/

Islas Rivera, V. (2000). Llegando tarde al compromiso: La crisis del transporte en la ciudad de México. Distrito Federal: El Colegio de México, Centro de Estudios Demográficos y de Desarrollo Urbano, Programa sobre Ciencia, Tecnología y Desarrollo.

Lee, Y., Washington, S., \& Frank, L. (2009). Examination of relationships between urban form, household activities, and time allocation in the Atlanta metropolitan region. Transportation Research Part A: Policy and Practice, 43(4), 360-373. doi.org/10.1016/j.tra.2008.11.013

Mills, E. (1972). Studies in the structure of the urban economy. Baltimore: The Johns Hopkins Press.

Mokhtarian, P., \& Cao, X. (2008). Examining the impacts of residential self-selection on travel behavior: A focus on methodologies. Transportation Research Part B: Methodological, 42(3), 204-228. doi. org/10.1016/j.trb.2007.07.006

Monkkonen, P. (2011). The housing transition in Mexico: Expanding access to housing finance. Urban Affairs Review, 47(5), 672-695. doi.org/10.1177/1078087411400381

Montejano, J., Caudillo, C., \& Cárdenas, J. (2016). Contesting Mexico City's alleged polycentric condition through a centrality-mixed land-use composite index. Urban Studies, 53 (11), 2380-2396. doi.org/10.1177/0042098015588685

Muth, R. (1969). Cities and housing; The spatial pattern of urban residential land use. Chicago: University of Chicago Press. 
OECD. (2015). OECD territorial reviews: Valle de México, Mexico. Paris: OECD Publishing.

OpenStreetMap Wiki contributors. (2015). OpenStreetMap Wiki. Retrieved from http://wiki.openstreetmap.org/wiki/Main_Page

Parry, I., \& Strand, J. (2012). International fuel tax assessment: An application to Chile. Environment and Development Economics, 17(2), 127-144. doi.org/10.1017/S1355770X11000404

Rajamani, J., Bhat, C., Handy, S., Knaap, G., \& Song, Y. (2003). Assessing impact of urban form measures on nonwork trip mode choice after controlling for demographic and level-of-service effects. Transportation Research Record, 1831(1), 158-165. doi.org/10.3141/1831-18

Schwanen, T., \& Mokhtarian, P. (2005). What if you live in the wrong neighborhood? The impact of residential neighborhood type dissonance on distance traveled. Transportation Research Part D: Transport and Environment, 10(2), 127-151. doi.org/10.1016/j.trd.2004.11.002

SETRAVI. (2013). Portal de la Secretaría de Transportes y Vialidad del Gobierno del Distrito Federal. Retrieved from http://www.setravi.df.gob.mx/index.jsp

Small, K., \& Verhoef, E. (2007). The economics of urban transportation (2nd ed.). New York: Routledge. Small, K., \& Winston, C. (1999). The demand for transportation: Models and applications. In J. Gomez-Ibanez, W. B. Tye, \& C. Winston (Eds.), Essays in transportation economics and policy: A handbook in honor of John R (pp. 11-56). Washington, D.C.: Brookings Institution Press.

Stevens, M. (2017). Does compact development make people drive less? Journal of the American Planning Association, 83(1), 7-18. doi.org/10.1080/01944363.2016.1240044

Suárez, M., \& Delgado, J. (2007). La expansión urbana probable de la Ciudad de México. Un escenario pesimista y dos alternativos para el año 2020. Estudios Demográficos y Urbanos, 22(1), 101-142.

Suárez, M., Murata, M., \& Delgado, J. (2016). Why do the poor travel less? Urban structure, commuting and economic informality in Mexico City. Urban Studies, 53(12) 2548-2566.

Train, K. (2009). Discrete choice methods with simulation (2nd ed.). New York: Cambridge University Press. Retrieved from http://elsa.berkeley.edu/books/choice2.html

van Wissen, L., \& Golob, T. (1992). A dynamic model of car fuel-type choice and mobility. Transportation Research Part B: Methodological, 26(1), 77-96. doi.org/10.1016/0191-2615(92)90021-N

Ward, P. (1998). Mexico City. West Sussex: John Wiley \& Sons Ltd.

Wirth, C. (1997). Transportation policy in Mexico City. Urban Affairs Review, 33(2), 155-181. doi. org/10.1177/107808749703300201

WRI Ross Center for Sustainable Cities. (2011, June 7). Snapshot/Martita [video file]. Retrieved from https://www.youtube.com/watch?v=NTQuhuyu6OA\&feature=youtube_gdata_player

Zegras, C. (2010). The built environment and motor vehicle ownership and use: Evidence from Santiago de Chile. Urban Studies, 47(8), 1793-1817. doi.org/10.1177/0042098009356125 


\section{Appendix}

Appendix A: Scaled binomial logit and OLS models of household transit expenditures

\begin{tabular}{|c|c|c|c|c|c|c|}
\hline & \multicolumn{5}{|c|}{ Dependent variable: } & \\
\hline & \multirow{2}{*}{\multicolumn{3}{|c|}{$\begin{array}{c}\text { Public transit use }>0 \\
\text { Logit models } \\
\end{array}$}} & \multicolumn{3}{|c|}{ Public transit expenditures $(\log )$} \\
\hline & & & & 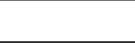 & OLS models & 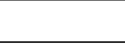 \\
\hline & $(1)$ & (2) & (3) & $(4))$ & $(5)$ & (6) \\
\hline & \multicolumn{6}{|c|}{ Urban form predictor variables } \\
\hline Kilometers to the metro & $\begin{array}{l}0.117^{*} \\
(0.070)\end{array}$ & $\begin{array}{l}-0.038 \\
(0.075)\end{array}$ & $\begin{array}{c}-0.04 \\
(0.077)\end{array}$ & $\begin{array}{c}0.350^{* * *} \\
(0.021)\end{array}$ & $\begin{array}{c}0.343^{* * *} \\
(0.021)\end{array}$ & $\begin{array}{c}0.326^{* * *} \\
(0.020)\end{array}$ \\
\hline Kilometers to the metro (squared) & $\begin{array}{c}-0.387^{* * *} \\
(0.077)\end{array}$ & $\begin{array}{l}-0.058 \\
(0.083)\end{array}$ & $\begin{array}{c}0.045 \\
(0.086)\end{array}$ & $\begin{array}{c}-0.213^{* * *} \\
(0.023)\end{array}$ & $\begin{array}{c}-0.199^{* * *} \\
(0.023)\end{array}$ & $\begin{array}{c}-0.124^{* * *} \\
(0.022)\end{array}$ \\
\hline Kilometers to the Zocalo & $\begin{array}{c}-0.490^{* * *} \\
(0.106)\end{array}$ & $\begin{array}{l}-0.146 \\
(0.111)\end{array}$ & $\begin{array}{l}-0.155 \\
(0.113)\end{array}$ & $\begin{array}{c}0.118^{* * *} \\
(0.031)\end{array}$ & $\begin{array}{c}0.128^{* * *} \\
(0.031)\end{array}$ & $\begin{array}{l}0.060^{* *} \\
(0.030)\end{array}$ \\
\hline Kilometers to the Zocalo (squared) & $\begin{array}{c}0.830^{* * *} \\
(0.122)\end{array}$ & $\begin{array}{l}0.275^{* *} \\
(0.127)\end{array}$ & $\begin{array}{c}0.142 \\
(0.128)\end{array}$ & $\begin{array}{c}-0.080^{* *} \\
(0.035)\end{array}$ & $\begin{array}{c}-0.098^{* * *} \\
(0.035)\end{array}$ & $\begin{array}{c}-0.157^{* * *} \\
(0.033)\end{array}$ \\
\hline Jobs per hectare & $\begin{array}{c}-0.063^{* * *} \\
(0.022)\end{array}$ & $\begin{array}{l}-0.037 \\
(0.023)\end{array}$ & $\begin{array}{l}-0.012 \\
(0.023)\end{array}$ & $\begin{array}{c}-0.051^{* * *} \\
(0.007)\end{array}$ & $\begin{array}{c}-0.054^{* * *} \\
(0.007)\end{array}$ & $\begin{array}{c}-0.045^{* * *} \\
(0.007)\end{array}$ \\
\hline People per hectare & $\begin{array}{c}0.324^{* * *} \\
(0.020)\end{array}$ & $\begin{array}{c}0.226^{* * *} \\
(0.021)\end{array}$ & $\begin{array}{c}0.194^{* * *} \\
(0.021)\end{array}$ & $\begin{array}{c}0.027^{* * *} \\
(0.006)\end{array}$ & $\begin{array}{c}0.023^{* * *} \\
(0.006)\end{array}$ & $\begin{array}{c}0.009^{*} \\
(0.005)\end{array}$ \\
\hline Destination diversity & $\begin{array}{c}-0.090^{* * *} \\
(0.018)\end{array}$ & $\begin{array}{c}-0.056^{* * *} \\
(0.019)\end{array}$ & $\begin{array}{c}-0.041^{* *} \\
(0.020)\end{array}$ & $\begin{array}{c}-0.059^{* * *} \\
(0.005)\end{array}$ & $\begin{array}{c}-0.057^{* * *} \\
(0.005)\end{array}$ & $\begin{array}{c}-0.049^{* * *} \\
(0.005)\end{array}$ \\
\hline \multirow[t]{2}{*}{ Intersections per hectare } & $\begin{array}{c}0.014 \\
(0.018) \\
\end{array}$ & $\begin{array}{c}0.024 \\
(0.019) \\
\end{array}$ & $\begin{array}{c}0.025 \\
(0.019) \\
\end{array}$ & $\begin{array}{c}0.014^{* * *} \\
(0.005)\end{array}$ & $\begin{array}{c}0.014^{* * *} \\
(0.005)\end{array}$ & $\begin{array}{c}0.017^{* * *} \\
(0.005)\end{array}$ \\
\hline & \multicolumn{6}{|c|}{ Socioeconomic predictor variables } \\
\hline Monthly income (nat. log) & $\begin{array}{c}-2.019^{* * *} \\
(0.061)\end{array}$ & $\begin{array}{c}-0.778^{* * *} \\
(0.067)\end{array}$ & $\begin{array}{c}-0.986^{* * *} \\
(0.069)\end{array}$ & $\begin{array}{c}0.025 \\
(0.018)\end{array}$ & $\begin{array}{c}0.079^{* * *} \\
(0.019)\end{array}$ & $\begin{array}{l}-0.029 \\
(0.018)\end{array}$ \\
\hline Income missing & $\begin{array}{c}-2.130^{* * *} \\
(0.062)\end{array}$ & $\begin{array}{c}-0.884^{* * *} \\
(0.068)\end{array}$ & $\begin{array}{c}-1.088^{* * *} \\
(0.070)\end{array}$ & $\begin{array}{c}0.012 \\
(0.018)\end{array}$ & $\begin{array}{c}0.065^{* * *} \\
(0.019)\end{array}$ & $\begin{array}{c}-0.038^{* *} \\
(0.018)\end{array}$ \\
\hline People over 6 & $\begin{array}{c}0.394^{* * *} \\
(0.021)\end{array}$ & $\begin{array}{c}0.384^{* * *} \\
(0.022)\end{array}$ & $\begin{array}{c}0.428^{* * *} \\
(0.023)\end{array}$ & $\begin{array}{c}0.086^{* * *} \\
(0.005)\end{array}$ & $\begin{array}{c}0.087^{* * *} \\
(0.005)\end{array}$ & $\begin{array}{c}0.100^{* * *} \\
(0.005)\end{array}$ \\
\hline People 6 or under & $\begin{array}{c}-0.143^{* * *} \\
(0.016)\end{array}$ & $\begin{array}{c}-0.195^{* * *} \\
(0.017)\end{array}$ & $\begin{array}{c}-0.197^{* * *} \\
(0.017)\end{array}$ & $\begin{array}{c}-0.055^{* * *} \\
(0.005)\end{array}$ & $\begin{array}{c}-0.056^{* * *} \\
(0.005)\end{array}$ & $\begin{array}{c}-0.055^{* * *} \\
(0.004)\end{array}$ \\
\hline Workers & $\begin{array}{c}0.304^{* * *} \\
(0.020)\end{array}$ & $\begin{array}{c}0.309^{* * *} \\
(0.021)\end{array}$ & $\begin{array}{c}0.126^{* * *} \\
(0.023)\end{array}$ & $\begin{array}{c}0.145^{* * *} \\
(0.006)\end{array}$ & $\begin{array}{c}0.146^{* * *} \\
(0.005)\end{array}$ & $\begin{array}{c}0.070^{* * * *} \\
(0.006)\end{array}$ \\
\hline Average age of adults & $\begin{array}{c}0.057 \\
(0.108)\end{array}$ & $\begin{array}{c}0.655^{* * *} \\
(0.117)\end{array}$ & $\begin{array}{c}0.532^{* * *} \\
(0.119)\end{array}$ & $\begin{array}{c}0.314^{* * *} \\
(0.033)\end{array}$ & $\begin{array}{c}0.336^{* * *} \\
(0.033)\end{array}$ & $\begin{array}{c}0.287^{* * *} \\
(0.031)\end{array}$ \\
\hline \multirow[t]{2}{*}{ Average age (squared) } & $\begin{array}{l}-0.169 \\
(0.107) \\
\end{array}$ & $\begin{array}{c}-0.715^{* * *} \\
(0.115) \\
\end{array}$ & $\begin{array}{c}-0.590^{* * *} \\
(0.117) \\
\end{array}$ & $\begin{array}{c}-0.336^{* * *} \\
(0.033) \\
\end{array}$ & $\begin{array}{c}-0.356^{* * *} \\
(0.033) \\
\end{array}$ & $\begin{array}{c}-0.308^{* * *} \\
(0.031)\end{array}$ \\
\hline & \multicolumn{6}{|c|}{ Endogenous control variables } \\
\hline Has a vehicle & - & $\begin{array}{c}-0.863^{* * *} \\
(0.019)\end{array}$ & $\begin{array}{c}-0.891^{* * *} \\
(0.019)\end{array}$ & - & $\begin{array}{c}-0.062^{* * *} \\
(0.005)\end{array}$ & $\begin{array}{c}-0.071^{* * *} \\
(0.005)\end{array}$ \\
\hline Monthly estimated rent (nat. $\log$ ) & - & $\begin{array}{c}-0.961^{* * *} \\
(0.066)\end{array}$ & $\begin{array}{c}-0.974^{* * *} \\
(0.067)\end{array}$ & - & $\begin{array}{c}0.025 \\
(0.019)\end{array}$ & $\begin{array}{c}0.017 \\
(0.018)\end{array}$ \\
\hline Rent missing & - & $\begin{array}{c}-0.999^{* * *} \\
(0.067) \\
\end{array}$ & $\begin{array}{c}-1.038^{* * *} \\
(0.068)\end{array}$ & - & $\begin{array}{c}0.042^{* *} \\
(0.019)\end{array}$ & $\begin{array}{c}0.024 \\
(0.018) \\
\end{array}$ \\
\hline
\end{tabular}


Appendix A: Scaled binomial logit and OLS models of household transit expenditures (continued)

\begin{tabular}{|c|c|c|c|c|c|c|}
\hline \multicolumn{7}{|c|}{ Commute trip characteristics } \\
\hline Worker 1: central destination & - & - & $\begin{array}{l}0.039^{* *} \\
(0.020)\end{array}$ & - & - & $\begin{array}{c}-0.050^{* * *} \\
(0.005)\end{array}$ \\
\hline Worker 2: central destination & - & - & $\begin{array}{c}0.102^{* * *} \\
(0.027)\end{array}$ & - & - & $\begin{array}{c}0.028^{* * *} \\
(0.007)\end{array}$ \\
\hline Worker 3: central destination & - & - & $\begin{array}{c}0.049^{*} \\
(0.028)\end{array}$ & - & - & $\begin{array}{c}0.003 \\
(0.007)\end{array}$ \\
\hline Worker 1: commute distance $(\mathrm{km})$ & - & - & $\begin{array}{c}0.313^{* * *} \\
(0.021)\end{array}$ & - & - & $\begin{array}{c}0.179^{* * *} \\
(0.005)\end{array}$ \\
\hline Worker 2: commute distance $(\mathrm{km})$ & - & - & $\begin{array}{c}0.235^{* * *} \\
(0.031)\end{array}$ & - & - & $\begin{array}{c}0.135^{* * *} \\
(0.007)\end{array}$ \\
\hline Worker 3: commute distance $(\mathrm{km})$ & - & - & $\begin{array}{c}0.028 \\
(0.033)\end{array}$ & - & - & $\begin{array}{c}0.022^{* * *} \\
(0.007)\end{array}$ \\
\hline Constant & $\begin{array}{c}1.564^{* * *} \\
(0.016)\end{array}$ & $\begin{array}{c}1.810^{* * *} \\
(0.020)\end{array}$ & $\begin{array}{c}1.867^{* * *} \\
(0.020)\end{array}$ & $\begin{array}{c}2.927^{* * *} \\
(0.005)\end{array}$ & $\begin{array}{c}2.927^{* * *} \\
(0.004)\end{array}$ & $\begin{array}{c}2.926^{* * *} \\
(0.004)\end{array}$ \\
\hline Observations & 31,167 & 31,167 & 31,167 & 24,911 & 24,911 & 24,911 \\
\hline McFadden $\mathrm{R}^{2}$ & 0.103 & 0.200 & 0.223 & 0.189 & 0.195 & 0.281 \\
\hline Log Likelihood & $-14,021$ & $-12,495$ & $-12,145$ & $-26,821$ & $-26,730$ & $-25,323$ \\
\hline
\end{tabular}

Notes: Standard errors in parentheses, ${ }^{*} \mathrm{p}<0.1 ;{ }^{* *} \mathrm{p}<0.05 ;{ }^{* * *} \mathrm{p}<0.01$

Appendix B: Tobit models predicting total household transit expenditures

\begin{tabular}{lccc}
\hline & \multicolumn{3}{c}{ Dependent variable: } \\
\cline { 2 - 4 } & \multicolumn{3}{c}{ Public transit use $>\mathbf{0}$} \\
\cline { 2 - 4 } & Urban form predictor variables & $(\mathbf{1})$ & $(\mathbf{3})$ \\
\hline Kilometers to Metro & $0.047^{* * *}$ & $0.034^{* * *}$ & $0.032^{* * *}$ \\
Kilometers to Metro (squared) & $(0.004)$ & $(0.005)$ & $(0.005)$ \\
Kilometers to Zocalo & $-0.002^{* * *}$ & $-0.001^{* * *}$ & $-0.000^{* *}$ \\
& $(0.000)$ & $(0.000)$ & $(0.000)$ \\
Kilometers to Zocalo (squared) & $-0.019^{* * *}$ & -0.001 & -0.001 \\
Jobs per hectare & $(0.019)$ & $(0.006)$ & $(0.006)$ \\
& $0.001^{* * *}$ & 0.000 & 0.000 \\
People per hectare & $(0.000)$ & $(0.000)$ & $(0.000)$ \\
& $-0.002^{* * *}$ & $-0.002^{* * *}$ & $-0.001^{* * *}$ \\
Destination diversity & $(0.002)$ & $(0.000)$ & $(0.000)$ \\
& $0.002^{* * *}$ & $0.002^{* * *}$ & $0.001^{* * *}$ \\
Intersections per hectare & $(0.000)$ & $(0.000)$ & $(0.000)$ \\
& $-0.006^{* * *}$ & $-0.005^{* * *}$ & $-0.004^{* * *}$ \\
& $(0.001)$ & $(0.001)$ & $(0.001)$ \\
& $0.011^{*}$ & 0.011 & $0.013^{* *}$ \\
& $(0.007)$ & $(0.006)$ & $(0.006)$ \\
\hline
\end{tabular}


Appendix B: Tobit models predicting total household transit expenditures (continued)

\begin{tabular}{|c|c|c|c|}
\hline \multicolumn{4}{|c|}{ Socioeconomic predictor variables } \\
\hline Monthly income (nat. log) & $\begin{array}{c}-0.409^{* * *} \\
(0.012)\end{array}$ & $\begin{array}{c}-0.147^{* * *} \\
(0.013)\end{array}$ & $\begin{array}{c}-0.209^{* * *} \\
(0.013)\end{array}$ \\
\hline Income missing & $\begin{array}{c}-4.016^{* * *} \\
(0.116)\end{array}$ & $\begin{array}{c}-1.579^{* * *} \\
(0.120)\end{array}$ & $\begin{array}{c}-2.120^{* * *} \\
(0.116)\end{array}$ \\
\hline People over 6 & $\begin{array}{c}0.128^{* * *} \\
(0.005)\end{array}$ & $\begin{array}{c}0.116^{* * *} \\
(0.005)\end{array}$ & $\begin{array}{c}0.125^{* * *} \\
(0.005)\end{array}$ \\
\hline People 6 or under & $\begin{array}{c}-0.169^{* * *} \\
(0.013)\end{array}$ & $\begin{array}{c}-0.190^{* * *} \\
(0.012)\end{array}$ & $\begin{array}{c}-0.183^{* * *} \\
(0.012)\end{array}$ \\
\hline Workers & $\begin{array}{c}0.283^{* * *} \\
(0.010)\end{array}$ & $\begin{array}{c}0.265^{* * *} \\
(0.010)\end{array}$ & $\begin{array}{c}0.132^{* * *} \\
(0.010)\end{array}$ \\
\hline Average age of adults & $\begin{array}{c}0.053^{* * *} \\
(0.009)\end{array}$ & $\begin{array}{c}0.090^{* * *} \\
(0.009)\end{array}$ & $\begin{array}{c}0.075^{* * *} \\
(0.008)\end{array}$ \\
\hline Average age (squared) & $\begin{array}{c}-0.001^{* * *} \\
(0.000)\end{array}$ & $\begin{array}{c}-0.001^{\text {*** }} \\
(0.000)\end{array}$ & $\begin{array}{c}-0.001^{* * *} \\
(0.000)\end{array}$ \\
\hline \multicolumn{4}{|c|}{ Endogenous control variables } \\
\hline Has a vehicle & - & $\begin{array}{c}-0.917^{* * *} \\
(0.019)\end{array}$ & $\begin{array}{c}-0.922^{* * *} \\
(0.018)\end{array}$ \\
\hline Monthly estimated rent (nat. log) & - & $\begin{array}{c}-0.205^{* * *} \\
(0.013)\end{array}$ & $\begin{array}{c}-0.203^{* * *} \\
(0.013)\end{array}$ \\
\hline Rent missing & - & $\begin{array}{c}-1.557^{* * *} \\
(0.100)\end{array}$ & $\begin{array}{c}-1.594^{* * *} \\
(0.096)\end{array}$ \\
\hline \multicolumn{4}{|l|}{ Commute trip characteristics } \\
\hline Worker 1: central destination & - & - & $\begin{array}{c}-0.059^{* * *} \\
(0.019)\end{array}$ \\
\hline Worker 2: central destination & - & - & $\begin{array}{c}0.175^{* * *} \\
(0.032)\end{array}$ \\
\hline Worker 3: central destination & - & - & $\begin{array}{c}0.093^{* *} \\
(0.045)\end{array}$ \\
\hline Worker 1: commute distance $(\mathrm{km})$ & - & - & $\begin{array}{c}0.029^{* * *} \\
(0.001)\end{array}$ \\
\hline Worker 2: commute distance $(\mathrm{km})$ & - & - & $\begin{array}{c}0.028^{* * *} \\
(0.002)\end{array}$ \\
\hline Worker 3: commute distance $(\mathrm{km})$ & - & - & $\begin{array}{c}0.004 \\
(0.003)\end{array}$ \\
\hline Constant & $\begin{array}{c}3.881^{* * *} \\
(0.201)\end{array}$ & $\begin{array}{c}2.780^{* * *} \\
(0.205)\end{array}$ & $\begin{array}{c}3.577^{* * *} \\
(0.197) \\
\end{array}$ \\
\hline Observations & 31,167 & 31,167 & 31,167 \\
\hline McFadden $\mathrm{R}^{2}$ & 0.099 & 0.125 & 0.144 \\
\hline Log Likelihood & $-53,109$ & $-51,575$ & $-50,499$ \\
\hline
\end{tabular}

Notes: Standard errors in parentheses, ${ }^{*} \mathrm{p}<0.1 ;{ }^{* *} \mathrm{p}<0.05 ;{ }^{* * *} \mathrm{p}<0.01$ 